\title{
AXL Inhibitor DS-1205c
}

National Cancer Institute

\section{Source}

National Cancer Institute. AXL Inhibitor DS-1205c. NCI Thesaurus. Code C152976.

An orally available and selective inhibitor of the receptor tyrosine kinase AXL (UFO), with potential antineoplastic activity. Upon administration, DS-1205c targets, binds to and prevents the activation of AXL. This blocks AXL-mediated signal transduction pathways and inhibits tumor cell proliferation and migration. AXL, a member of the Tyro3, AXL and Mer (TAM) family of receptor tyrosine kinases, is overexpressed by many tumor cell types. It plays a key role in tumor cell proliferation, survival, invasion and metastasis; its expression is associated with drug resistance and poor prognosis. 